\title{
THE MANUFACTURE OF SOLE LEATHER FROM THE HYGIENIC POINT OF VIEW.
}

\author{
By P. F. SPARIE EVANS.
}

T PURPOSE to commence by griving you a short sketch of the manu1 facture of sole leather, so that we may be able to appreciate the manner in which this affects hygiene.

Many people think that tanning is akin to farming, believing that one has only to wait while hides tan and corn grows; but I can assure you it is not so simple a matter.

Bristol has long been noted for its thick sole leather, and the term "Bristol butts" is well known in the trade. These were formerly made from hides imported in large quantities from South America; where, to within the last fifteen years, before the advent of such commodities as Lemco, Oxo, Bovril, \&c., the animals were principally bred for the sake of their hides, which became very thick, owing to the cattle living practically in a wild state.

Now, with the importation into South America of English bulls for breeding purposes, the hide is much larger and thinner; and at the same time the demand for the very heary leather of twenty years ago has diminished to a very marked extent, owing to cycles, motors, electric and other trams, in short to the decreased amount of walking done by people.

Bristol tanners, in common with their confreres throughout the country, have therefore turned their attention to lighter hides, notably those from English and Continental markets.

The method of turning hides into leather may be classed under three heads, each of which is a process in itself.

First the preparation of the hides to take the tan.

Second tanning, or converting the hide-substance into leather.

Third finishing, or preparing the leather for market.

Taking these in order, we come first to the lime yard. This part of the process includes the reception, cleansing, liming, unhairing, fleshing, classifying and deliming of the goods. 
The hides are placed in several changes of water, for from six to forty-eight hours. This remores any dirt, blood, \&c., and prepares the hides for the liming process (which is the most general one) and consists in treating them with ordinary lime dissolved in water. This solution causes a swelling to take place, and facilitates the removal of the hair. The hides remain in a series of three or four solutions for at total time of from ten to fourteen days. They are then ready to be mnhaired. This was formerly done with a blunt knife, but in most yards machines are now used. After unhairing, they are put into clean water, and the flesh is then removed by a sharp knife or machine, great care being required to prevent damage. They are then trimmed into various forms, sorted and agrain put into water. This washing is very important, for as much as possible of the lime must be removed before tanning, since excess of this substance, in combination with the tan, produces it bad colour when finished.

Secondly, tanning.-This part of the process has undergone many changes in the past twenty years.

Until then, eighteen to twenty-four months to leave the hicle in tan was not at all an uncommon time, the chief agent employed being oak-bark. But at the present time tanning takes from four to eight months, althongh it is claimed ly a certain patented process, that it can be clone even in two days. In reality, the quicker the time the less valuable the leather; very fow of the mockern leathers comparing farourably with the oak-bark longprocess tamiage of fifty years ago. The shortening of this process is achieved by michinery and by the use of imported concentrater tanning materials. Prior to twenty years ago nearly all materials came in bulk, but now by far the largest amount is shipped to this country in the form of extracts, which contain from 25 to 60 per cent. of tan, whereas the bulk materials, from which they are made, contain only 4 to 35 per cent.

The chief materials used in tanning are :-

Oak bark, obtained from Great Britain and Belgium. It contains from 6 to 10 per cent. tan, and produces firm leather with a yellow-red tinge.

Mimosa, from Australia and Natal. The bark of the Wattle tree (acacia) contains 30 to 40 per cent. tan, is quick in action, and produces a light weighing, somewhat pink leather.

Valonia, from Smyrna and Greece. The fruit of the Quercus Egilops, or Turkish oak, contains 30 to 40 per cent. tan, is slow in action, and produces hard, grey leather.

Myrabolames, from India. The fruit of a tree, contains 30 to 40 per 
cent. tan of a very penetrating kind, and produces soft, light-weighing leather, rather yellow.

Sumac, from Sicily, a preparation from the leaves of a tree, contains 20 to 30 per cent. tan, producing soft, light-weighing leather with a light colour.

Quebracho, from South America. Is an extract from the wood of the Qucbracho tree, contains 50 to 70 per cent. tan, which is very quick in action, and produces a light-weighing, pink leather.

Gambier, from the Straits Settlements. An extract from the leaves and twigs of the Gambier shrub, contains 30 to 40 per cent. tan, is very quick in its action, and is used principally in the earlicr stages of the process.

Mangrove, from Bornco. An extract from the Mangrove tree, contains 50 to 60 per cent. tan, gires sof tness to the leather, which is red.

Oakwood extract, from Hungary, obtained from the wood of the Slavonian Oak tree, contnins 24 to 28 per cent. tan, gives weight and firmness to the leather, which is ycllow-brown.

Chesnut extract, from France, Spain and Corsica, obtained from the wood of the Chesnut tree, contains 28 to 33 per cent. tan, gives weight and firmness, with a lighter colour than that obtained by Oakwood extract.

The slill of the tanner is shown in blending the different materials in such proportions as to produce the desired result.

The tamning process is divided into three stages, "poles," "handlers," and "layers."

One of the first aims of a tanner is to get a good colour, and as much weight in his leather as is possible by legitimate means. This is done by allowing the tanning agents to combine with the hides, which are, first of all, suspended on poles in weak liquors, for the double purpose of taking out any lime left in from the preliminary stages in the lime yard, and of swelling and colouring the hide.

Time on poles, eight to twenty days. Series of pits used. They are then removed from the poles, and undergo the second stage of the process, termed " handlers," in which they are constantly slifted. Time, four to eight weeks. Series of pits of increasing strengths.

The third stage, termed "layers," explains itself, and consists in laying the hides away in pits with a certain quantity of material between each. After this they are scoured by machine, in order to take out the creases and to clean the grain. Some tanners then further treat their hides with a bleaching extract in order to brighten the colour, although this is detrimental to the leather, owing to the acid action of the bi-sulphites which most bleaching extracts contain. 
The third process is that of finishing. This is really putting a face on, and rolling the leather, so as to make it still more water resistant, and to turn it out as a finished article with a pleasing appearance ready for the boot manufacturer. Time required, fourteen to twenty-one days.

Now that we have considered the legitimate manufacture of leather, we come to the second half of our subject, adulteration.

This is done for two reasons, to brighten the colour and to add weight, in order to be able to sell at a low price or to get an increased profit. The chief offenders in this way are, I am grlacl to say, not British, but American and continental tanners, and to some extent our Australian cousins, who have been in the habit of using chloride of barium for this purpose. Recent advices from Australia indicate, however, that the Government are bringing pressure to stop this practice.

It is harelly necessary to mention that the chief object of tanning is to make leather resistant to water for as long a time as possible. This can be done by the use of proper timning materials for a necessary time, and the better a leather is tanned and finished (whereby the cells of the hide are filled with tanning matter) the longer it resists water.

The object of some American tanners seems to be to carry out this process as cheaply as possible, with an unreasonalble minimum of tanningr material, and in too short a time. They are then confronted with a light-weighing leather. To remedy this, and also for the sake of extra profit, they have recourse to filling their leather with weighting materials. Among these are glucose, $\mathrm{E}_{\mathrm{p} s o m}$ salts, and barium. Now these adulterants, not being tanning materials, will not combine with the leather at all. They are simply deposited in or on the fibres only so long as no water is applied, but directly water is applied the adulterant dissolves, washes out, and leaves a poorly-tamned, very porous, non-water-resisting leather; hence, as can be easily under'stool, the wearer of such leather is subject to damp feet with its attendant ailments.

The adulteration of American leather is of somewhat recent growth, and it seems clear that a good portion of the blame must rest on the British public, whose one idea seems to be cheapness. Until within the last ten year's or so, the American tanner has been able to meet this demand for very cheap leather by the use of the hemlock tree bark. Whole forests have been cut down, and as these trees take many years to grow, the supply is naturally restricted, especially as replanting has not been resorted to to an alequate extent. The result is that the tamners have been obliged to go farther afield for their material, their railway carriage is dearer, and they have been forced to use other and more 
572 Manufacture of Sole Leather from the Hygicnic I'oint of View.

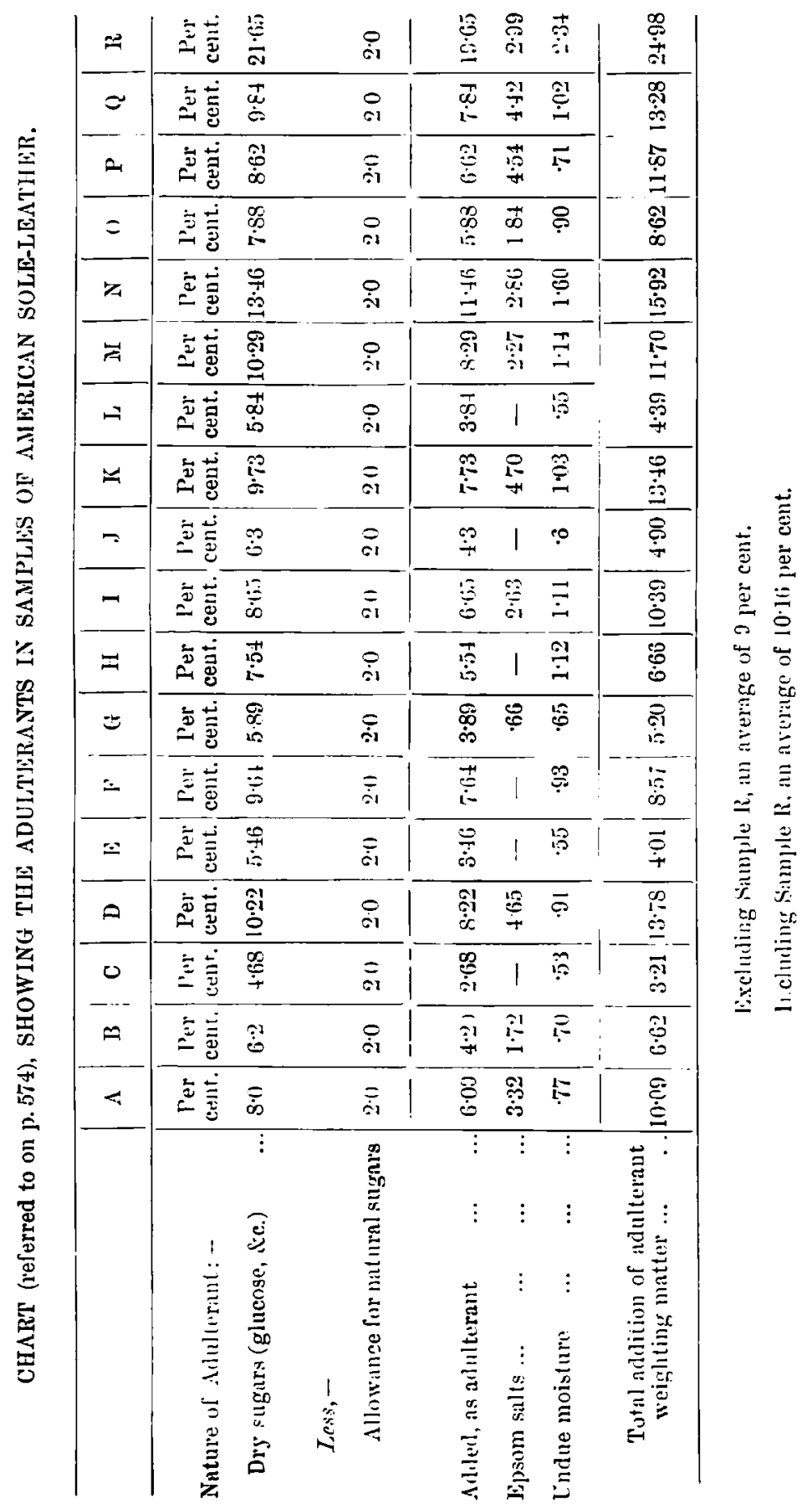


expensive substances; and having still to procure a low-priced leather, they have consequently had recourse to the use of non-tanning but weightgiving adulterants.

There are various ways of arlulterating leather after the tanning process is finished. One consists of placing it in a revolving drum containing a warm glucose solution. Another is to make a syrup and paste it upon the flesh side of the hide.

To the minitiated, glucose in leather is somewhat difficult to detoct, especially in dry weather, but on exposure to damp it soon manifests itself, if any considerable quantity is present. The leather then at once begins to feel sticky, owing to the glutinous matter oozing out. Cases have been known where bales of American splits, or upper leather, could not be unrolled, the skins being stuck together. One leather merchant known to the writer, suspecting that a shipment from America was not quite right, decided before sending out the consignment, to have some of it made up into boots, and at the present time a pair of these is hanging in his office; and is, as he says, the best weather-prophet he has ever had, a sure signal of approaching rain being the exudation of moisture, owing to the glucose present coming out in solution.

Speaking from personal knowledge, only the other day we had a sample of sole-leather sent to us from New Zealand, to match. It was certainly a beautiful colour, but, on the application of the water test, it was found that ten minutes after water poured through. Now the usual time for a good leather to resist water is from two to four days, and I have seen samples showing no dampness even after twenty-one days.

This New Zealand sample, after being treated with water, was allowed to stand for two days, when a white deposit, like mildew, was noted on the bottom side. This was found to consist of crystalline sodium sulphate. Needless to say, we did not match the leather in this respect.

The question of adulteration had recently been greatly exercising the minds of the hest English tammers, and realising the great importance of the question, not only to tanners, but to society at large, some of the Bristol. and northern tanners combined to conclict an inrestigation, in order to ascertain to what extent American leather was adulterated.

In summarising the ontcome of this, I wish to acknowledge my indebtedness to the "Year Book of the Manchester and Liverpool Tanners" Federation," whence the figures put hefore you have heen gleaned.

To fairly represent the general run of imports from America, eighteen samples of leather were procured from various sources. These were taken, not because they were suspected of being adulterated, but simply to get a 


\section{Manufacture of Sole Leather from the Hygienic Point of Vicw.}

fair average representation. They were sent to two of the foremost analytical chemists of the leather trade, Dr. J. Gordon Parker, of London, and Dr. Turnbull, of Liverpool, whose dictum cannot be questioned, and who did not know their origin. Their report was even worse than anyone expected would be the case; the Table on page 572 will show you plainly the tremendous extent to which these leathers were adulterated, and these samples were representative, and not selected as being specially suspected. The chemists made every allowance for the natural amount of sugary matter which is present to a small and varying extent in all tanning agents, and for slight moisture, which is inseparable from such materials, and their analysis may be taken as showing absolutely the added adulterant matter and moisture.

I will not go step by step through the whole case, but will generalise the results, and show to what a great extent adulteration has taken place, and what a loss to the user this means. One sample was so exceptionally bad that we will exclude it, so as to be just to the remaining serenteen.

In these we find an average of 7 per cent. added glucose and 2 per cent. Epsom salts. On this average, and on the basis of leather imported from the United States for the year ending June 30th, 1905, a total of $24,090,449 \mathrm{lbs}$., at an avernge cost of $9 \cdot 3$ pence per $1 \mathrm{~b}$., this 9 per cent. of useless, and even deleterious adulterant cost the British public $\mathfrak{e} 84,015$ ss. fid.

The weight of the glucose would be 753 tons, which, at $£ 1110 \mathrm{~s}$. ()d. per ton, gives $\mathfrak{E} 8$, 659 . The Epsom salts would weigh 215 tons, and this, at $£ 35$ s. Ocl. per ton, gives $£ 6918$. In fact, we paid $£ 84,000$ for what cost

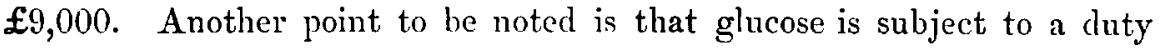
here of 2s. $9 \mathrm{~d}$. per cwt. and being smuggled in as leather, duty free, the 753 tons defrauded our treasury of $\mathfrak{2} 2,000$ duty.

Now, finally, let me again emphasise that leather adulterated with glucose and Epsom salts cannot afford the protection against water as can leather which is free from these materials. Still, if anyone likes damp, feet, let him be shod with sugar and salt; but the British public would find it more profitable to buy their glucose as glucose at alout $1 \frac{1}{4} d$. per $1 b$., and not as leather, costing between 1s. 2d. and 1s. 6d. per lb. 